\title{
EWOLUCJA STANDARDÓW SPRAWOZDAWCZOŚCI WEDKUG SEGMENTÓW DZIAŁALNOŚCI W RAMACH IFRS I JEJ UWARUNKOWANIA
}

Słowa kluczowe: MSR14, MSR14R, MSSF8, sprawozdanie według segmentów działalności, standardy sprawozdawczości według segmentów działalności.

\begin{abstract}
Abstrakt: W historii Międzynarodowych Standardów Sprawozdawczości Finansowej wyróżnia się trzy standardy poświęcone sprawozdawczości według segmentów działalności. Należą do nich: IAS14, IAS14R oraz IFRS8. Celem artykułu jest prezentacja zmian, jakie zaszły między tymi standardami, oraz ocena ich zasadności. W związku z tym zostaną przytoczone najważniejsze uregulowania prawne powyższych standardów, do których należy zaliczyć: rodzaj wyodrębnianych segmentów działalności, procedurę segmentacji działalności, kryteria uznania segmentów działalności za segmenty sprawozdawcze oraz wymagane do ujawnienia informacje finansowe na temat tak zidentyfikowanych obszarów działalności. Rozważaniom zostanie również poddana kwestia przyczyn, które doprowadziły do rozpoczęcie prac na nowymi standardami, powodując w konsekwencji ich zmianę. Zostaną także zaprezentowane wyniki ważniejszych badań empirycznych oraz płynące z nich wnioski na temat standardów sprawozdawczości według segmentów działalności oraz zasadności ich zmiany.
\end{abstract}

\section{THE EVOLUTION OF SEGMENT REPORTING STANDARDS UNDER IFRS AND ITS DETERMINANTS}

Keywords: IAS14, IAS14R, IFRS8, segment reporting, segment reporting standards.

Data wpłynięcia: 22.11.2012; data zaakceptowania: 25.02.2013.

* Dane kontaktowe: zimnicki@umk.pl, Katedra Rachunkowości, Wydział Nauk Ekonomicznych i Zarządzania, Uniwersy tet Mikołaja Kopernika, ul. Gagarina 13a, 87-100 Toruń, tel. 566114779. 


\begin{abstract}
In the history of International Financial Reporting Standards, there are three standards dedicated to segment reporting. These include IAS14, IAS14R and IFRS8. The purpose of this article is to present the changes which took place between the standards and assessment of their validity. Therefore, the will be presented the most important regulation of the above standards, which include: the type of isolated segments, business segmentation procedure, the criteria for the recognition of business segments for reporting segments and required financial information to be disclosed. Consideration shall be given to the question of the causes which led to the start of work on new standards, resulting in the consequences of the change. Also, there will be presented the results of empirical studies and the conclusions about segment reporting standard and the validity of their changes.
\end{abstract}

Translated by Tomasz Zimnicki

\title{
1II WsTĘP
}

Początki standaryzacji sprawozdawczości według segmentów działalności w ramach Międzynarodowych Standardów Sprawozdawczości Finansowej (ang. International Financial Accounting Standards, IFRS) sięgają 1980 r., kiedy to w marcu Komitet Międzynarodowych Standardów Rachunkowości (ang. International Accounting Standards Committee, IASC) wydał pierwszy poświęcony temu zagadnieniu projekt pod nazwą „Sprawozdawczość finansowa według segmentów działalności" (ang. Exposure Draft E15 Reporting Financial Information by Segment). W sierpniu 1981 r. został opublikowany pierwszy standard pod tą samą nazwą. Był nim Międzynarodowy Standard Rachunkowości nr 14 Sprawozdawczość finansowa według segmentów działalności (ang. International Accounting Standard No. 14 Reporting Financial Information by Segment, IAS14) ${ }^{1}$, który zaczynał obowiązywać od okresów sprawozdawczych rozpoczynających się 1 stycznia 1983 r. i później.

Na początku lat 90. IASC przystąpił do kolejnych prac nad poprawą sprawozdawczości według segmentów działalności. W wyniku tego w grudniu $1995 \mathrm{r}$. wydał projekt kolejnego standardu pod tą samą nazwą (ang. Exposure DraftE51 ReportingFinancialInformationbySegment).Poniespełnadwóchlatach,wsierpniu 1997 r., IASC opublikował nowy standard. Był nim Międzynarodowy Standard Rachunkowości nr 14 Sprawozdawczość dotycząca segmentów działalności (ang. International Accounting Standard No. 14 Segment Reporting, IAS14R)²,

1 Należy podkreślić, że w literaturze krajowej standard nie występuje, brakuje również polskiego tłumaczenia tego standardu.

2 Należy zwrócić uwagę, że w literaturze krajowej standard funkcjonuje pod nazwą Międzynarodowego Standardu Rachunkowości nr 14 Sprawozdawczość dotycząca seg- 
który zaczynał obowiązywać od okresów sprawozdawczych rozpoczynających się 1 lipca 1998 r. i później.

W połowie pierwszej dekady XXI w. Rada Międzynarodowych Standardów Rachunkowości (International Accounting Standards Board, IASB) - następca IASC, wspólnie z Radą Standardów Rachunkowości Finansowej (Financial Accounting Standards Board, FASB) przystąpiła do realizacji procesu konwergencji standardów rachunkowości. W wyniku tej współpracy w styczniu 2006 r. IASB wydała kolejny projekt standardu pod nazwą „Segmenty operacyjne” (ang. Exposure Draft 8 Operating Segments). Pod koniec tego samego roku, w listopadzie, wydano nowy standard poświęcony sprawozdawczości według segmentów. Był nim Międzynarodowy Standard Sprawozdawczości Finansowej nr 8 Segmenty operacyjne (ang. International Financial Reporting Standard No. 8 Operating Segments, IFRS8) ${ }^{3}$, który zaczynał obowiązywać od okresów sprawozdawczych rozpoczynających się 1 stycznia 2009 r. i później. Ten standard obowiązuje do dnia dzisiejszego.

Syntetycznej prezentacji zmian w standardach sprawozdawczości według segmentów działalności dokonano na schemacie 1.

Schemat 1. Zmiany w standardach sprawozdawczości według segmentów działalności

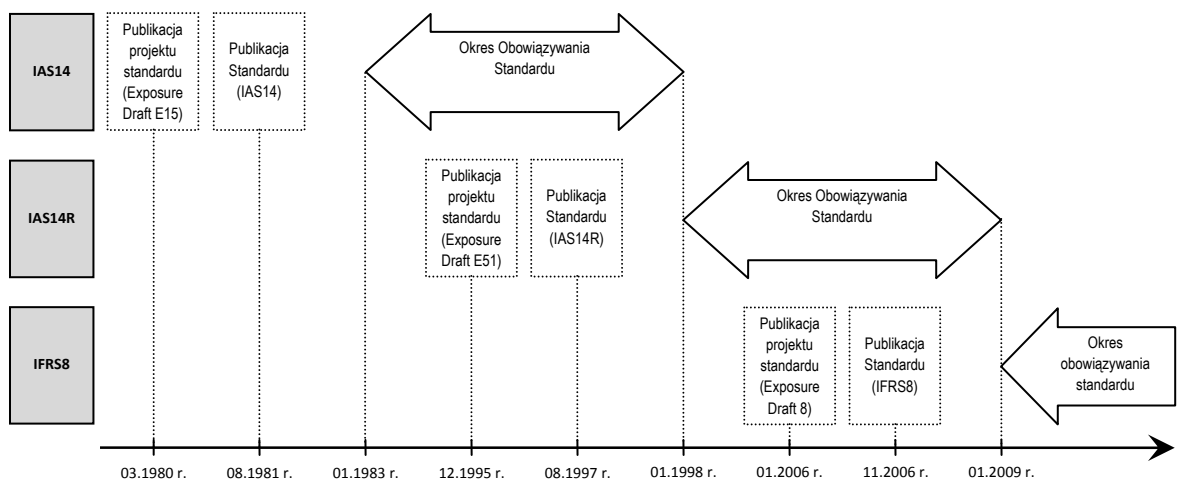

Źr ó dło : opracowanie własne.

mentów działalności (MSR 14), dostępne jest również jego polskie tłumaczenie (patrz: MSR 14 Sprawozdawczość dotycząca segmentów działalności, Międzynarodowe Standardy Sprawozdawczości Finansowej (MSSF) 2004, t. 1, SKwP, Warszawa 2004).

${ }^{3}$ Należy podkreślić, że w literaturze krajowej standard funkcjonuje pod nazwą Międzynarodowego Standardu Sprawozdawczości Finansowej nr 8 Segmenty operacyjne 
Celem artykułu jest prezentacja zmian zachodzących w standardach sprawozdawczości według segmentów działalności w ramach IFRS oraz ocena ich zasadności. W związku z tym zostaną przytoczone najważniejsze uregulowania prawne powyższych standardów, które uwidocznią zachodzące w nich zmiany. Rozważaniom zostaną również poddane przyczyny, które spowodowały rozpoczęcie prac nad nowymi standardami, a w konsekwencji zmianę obowiązujących. Zostaną także zaprezentowane wyniki ważniejszych badań empirycznych prowadzonych w tym zakresie, do których należy zaliczyć badania prowadzone przez Street i Bryant (2000), Street i Gray (2001), Street i Nichols (2002), Prather-Kinsey i Meek (2004), Świderską i Karwowskiego (2006), Street i Nichols (2007), Sojaka i Zimnickiego (2008) oraz Zimnickiego (2008) ${ }^{4}$.

Wnioski płynące z powyższych rozważań będą stanowić podstawę oceny zasadności zmian zachodzących w standardach sprawozdawczości według segmentów działalności. Zastosowaną metodą w pracy jest analiza krajowej i zagranicznej literatury przedmiotu.

\section{SPRAWOZDAWCZOŚĆ SEGMENTÓW DZIAŁALNOŚCI WEDŁUG IAS14}

IAS14 wyróżnia dwa rodzaje segmentów - segmenty przemysłowe i geograficzne. Przez te pierwsze należy rozumieć dające się wyodrębnić obszary jednostki gospodarczej, w ramach których następuje dystrybucja towarów lub świadczenie usług, bądź też grup powiązanych towarów lub usług, głównie na rzecz klientów zewnętrznych. Segmenty geograficzne, według standardu, to dające się wyodrębnić obszary jednostki gospodarczej, zaangażowane w działalność w danym kraju lub grupie krajów, przy czym dany obszar geograficzny charakteryzuje się specyficznym uwarunkowaniem (IAS14.5). Dodatkowo obszary te mogą zostać wyodrębnione na podstawie lokalizacji prowadzonej działalności lub rynków zbytu (IAS14.11). Zgodnie z wymogami standardu jednostka dokonuje podziału prowadzonej działalności na odrębne segmenty przemysłowe i geograficzne wówczas, gdy takie rodzaje działalności mają u niej zastosowanie (IAS14.10).

(MSSF 8), dostępne jest również jego polskie tłumaczenie (patrz: MSSF 8 Segmenty operacyjne, Międzynarodowe Standardy Sprawozdawczości Finansowej (MSSF) 2007, t. 1, SKwP, Warszawa 2007).

${ }^{4}$ Charakterystyki przytoczonych badań empirycznych dokonano w tabeli 1 zamieszczonej w załączniku nr 1. 
Podział działalności na odpowiednie segmenty jest dokonywany w oparciu o ocenę zarządu, który powinien wziąć przy tym pod uwagę następujące aspekty (IAS14.12):

- podobieństwa i różnice w zakresie zyskowności, ryzyka i możliwości rozwoju poszczególnych obszarów;

- występowanie odmiennych wymogów prawnych w tych obszarach;

- występowanie specyficznych cech charakterystycznych dla danego przemysłu.

IAS14 podkreśla, że jednostka ujawnia informacje tylko o segmentach określonych mianem sprawozdawczych. Za takie uważa tylko te segmenty działalności, które zdaniem jednostki są znaczące (IAS14.2). Proponuje zatem, ale nie wymaga, zastosowanie $10 \%$ kryterium istotności. Zgodnie z nim za znaczący segment działalności należy uznać ten, którego wynik, przychody lub aktywa stanowią co najmniej $10 \%$ tych wielkości dla jednostki jako całości. Trzeba zaznaczyć, że ostateczna decyzja w tym zakresie należy do zarządzających jednostką. Przy czym standard zaleca również rozważenie kwestii rozsądnej liczby ujawnianych segmentów w taki sposób, by nie prezentować ich zbyt dużo, co skutkowałoby zaciemnieniem obrazu jednostki (IAS14.15).

IAS14 określa również informacje, które należy ujawnić na temat każdego z wyodrębnionych segmentów sprawozdawczych - przemysłowych i geograficznych. Syntetycznie zaprezentowano je na schemacie 2 . 
Schemat 2. Informacje wymagane do ujawnienia przez IAS14

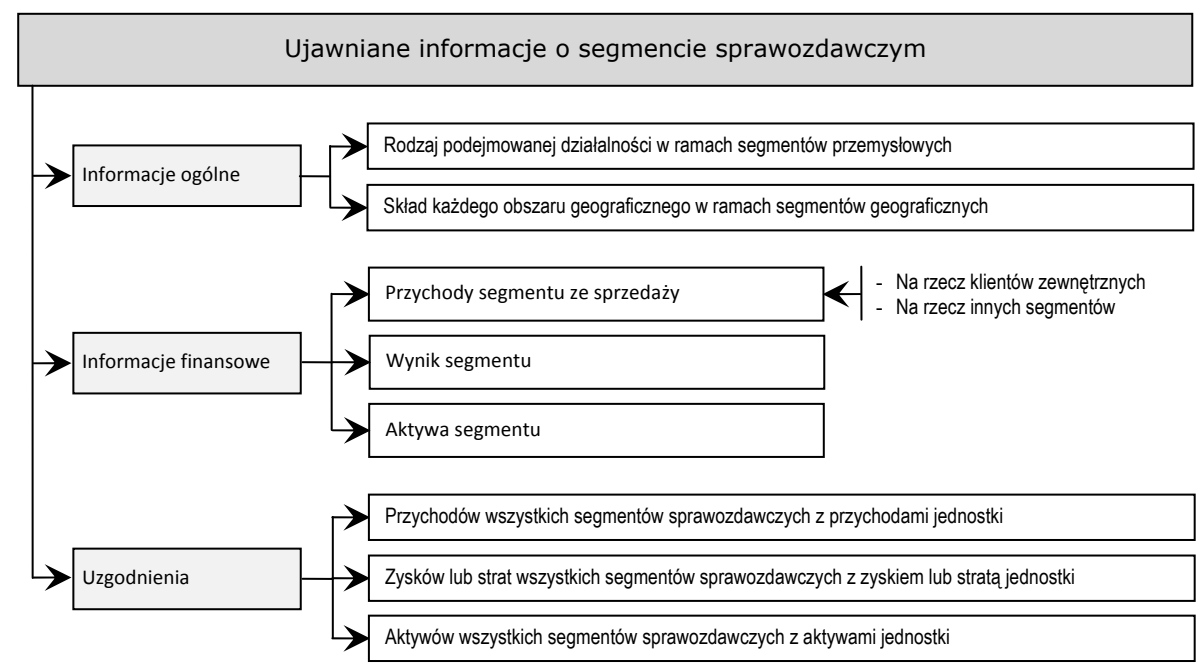

Źr ó dło: opracowanie własne na podstawie: International Accounting Standard 14 Reporting Financial Information by Segment, International Accounting Standards Committee Foundation, par. 9, 16, 21-23, http://www.ifrs.org (dostęp 4.11.2011).

\section{PRZYCZYNY ROZPOCZĘCIA PRAC NAD IAS14R}

IAS14 pod koniec lat 90. został zastąpiony przez IAS14R. Przyczyną rozpoczęcia prac nad nowym standardem sprawozdawczości według segmentów były w głównej mierze zidentyfikowane wady IAS14. Analiza zapisów standardu oraz prowadzone badania empiryczne zaliczyły do nich takie obszary, jak:

- zbyt ogólne definicje segmentów przemysłowych i geograficznych;

- mało precyzyjne wytyczne przy identyfikacji i pomiarze takich składowych segmentu, jak: przychody, koszty, wynik oraz aktywa;

- braki w ujawnieniach informacji o segmentach wymaganych przez standard;

- zbyt mała ilość prezentowanych informacji o segmentach.

Zbyt ogólne definicje segmentów przemysłowych i geograficznych uznano za jedną z głównych wad IAS14. Uwagę na to zwrócono w raporcie przygotowanym przez Paula Pactera. Stwierdzono tam, że standard zawiera jedynie ogólne wskazówki dotyczące określenia segmentów przemysłowych i geograficznych. Co więcej, nie występuje tam wymóg, by przeprowadzony podział 
działalności, w wyniku którego określa się segmenty sprawozdawcze, spełniał 75\% kryterium istotności (Pacter 1993: 40). Tę wadę podkreślili również analitycy finansowi, którzy stwierdzili, że wiele jednostek gospodarczych wykorzystuje zbyt szeroką definicję segmentów przemysłowych, stojąc na stanowisku, iż prowadzona przez nich działalność obywa się w ramach pojedynczego obszaru działalności, co zwalnia je z obowiązku ujawniania informacji o segmentach. Dodatkowo zwrócili oni też uwagę na zbyt szeroką definicję segmentów geograficznych. Ich zdaniem powoduje ona, że pewne jednostki grupują obszary geograficzne w oparciu o kryterium lokalne, inne - krajowe, a jeszcze inne - międzynarodowe, lub nawet kontynentalne, co ogranicza porównywalność tych informacji lub też całkowicie ją eliminuje (Street, Nichols 2002: 93). Tę wadę potwierdza również wydany w 1994 r. przez IASB dokument, który przedstawia wyniki analizy sprawozdań według segmentów działalności 1062 dużych jednostek gospodarczych z 32 krajów. Stwierdzono tam, że aż 28\% tych podmiotów ujawniło tylko jeden segment działalności (McConnell, Pacter 1995: 32-38).

Mało precyzyjne wytyczne przy identyfikacji i pomiarze takich składowych segmentu, jak: przychody, koszty, wynik oraz aktywa, uznano za kolejną wadę IAS14. Zwrócono na to uwagę we wspomnianym już raporcie przygotowanym przez Pactera, stwierdzając, że zawarte w standardzie definicje tego, co należy rozumieć za przychody, koszty oraz wynik segmentu, są mało precyzyjne (Pacter 1993: 40). Za wadę uznał to także IASC, twierdząc, że IAS14 powinien zostać zaktualizowany między innymi dlatego, by wprowadzić jasne wytyczne w zakresie identyfikacji i pomiaru wspomnianych składowych segmentu (Street, Nichols 2002: 93-94).

Za kolejną wadę IAS14 uznano braki w ujawnieniach informacji o segmentach wymaganych przez standard. Zwrócono na to uwagę w badaniu prowadzonym przez Donne L. Street i Stephanie M. Bryant, które poddały analizie sprawozdania finansowe 82 jednostek gospodarczych. Stwierdziły, że ujawniane informacje o segmentach przez badane podmioty mają istotne braki w stosunku do zakresu ujawnień wymaganych przez standard (Street, Bryant 2000: 305-329). Podobny wniosek zawarto w badaniu prowadzonym przez Donne L. Street i Sidney J. Gray. Poddały one analizie sprawozdania finansowe 279 jednostek gospodarczych. W wyniku tego stwierdziły, że ujawniane informacje o segmentach działalności przez badane podmioty są niepełne i znajdują się średnio na poziomie 76\% w stosunku do wymogów standardu (Street, Gray 2001: 75). 
Za wadę uznano również zbyt małą ilość prezentowanych informacji o segmentach. Zwrócili na to uwagę analitycy finansowi, którzy stwierdzili, że zakres ujawnianych informacji na temat poszczególnych segmentów działalności powinien być szerszy (Street, Nichols 2002: 93). Dodatkowo w 1990 r. Organizacja Współpracy Gospodarczej i Rozwoju (ang. Organization for Economic Co-operation and Development, OECD), Międzynarodowa Organizacja Komisji Papierów Wartościowych (ang. International Organization of Securities Commissions, IOSCO) oraz Organizacja Narodów Zjednoczonych (ang. United Nations, UN) zarekomendowały IASC zwiększenie zakresu ujawnianych informacji na temat segmentów działalności (Albrecht, Chipalkatti 1998: 46-51). Tę rekomendację IASC potraktowało poważnie, o czym może świadczyć stwierdzenie, że dokonując aktualizacji IAS14, należy rozważyć dodatkowe ujawnienia, które będą użyteczne z decyzyjnego punktu widzenia dla użytkowników sprawozdań finansowych (Street, Nichols 2002: 93-94).

Dodatkowo trzeba podkreślić, że w głównej mierze wyżej opisane wady stały się przyczyną rozpoczęcia prac nad IAS14R. Niemniej jednak Pacter we wspomnianym już raporcie stwierdził, że wpływ na to miały również takie zdarzenia, jak (Pacter 1993: 40):

- znaczący rozwój w zakresie sprawozdawczości według segmentów na świecie;

- implementacja IV Dyrektywy przez Komisję Europejską (ang. European Commission, EC);

- nowe wytyczne OECD dla sprawozdawczości według segmentów;

- rekomendacja Grupy Roboczej Organizacji Narodów Zjednoczonych dotycząca ujawniania informacji o segmentach;

- podjęcie prac nad poprawą sprawozdawczości według segmentów działalności w USA i Kanadzie;

- podkreślenie znaczenia obszaru sprawozdawczości według segmentów działalności dla IOSCO.

\section{SPRAWOZDAWCZOŚĆ SEGMENTÓW DZIAŁALNOŚCI WEDŁUG IAS14R}

IAS14R wyróżnia, podobnie jak poprzednik, dwa rodzaje segmentów działalności, z tym że są to segmenty branżowe i geograficzne. Przez segment branżowy IAS14R rozumie „dający się wyodrębnić obszar jednostki gospodarczej, w ramach którego następuje dystrybucja towarów lub świadczenie usług, lub grup powiązanych towarów lub usług, który podlega ryzyku i charakteryzu- 
je się zwrotem z poniesionych nakładów inwestycyjnych różnym od tych, które są właściwe dla innych segmentów branżowych" (IAS14R.9). Należy dodać, że dany segment może składać się z więcej niż jednego rodzaju towaru i usługi, ale pod warunkiem, że nie różnią się one istotnie poziomem realizowanych stóp zwrotu oraz stopniem ryzyka, a także spełniają kryterium podobieństwa w stosunku do większości czynników (IAS14R.11).

Za segment geograficzny standard uważa natomiast „dający się wyodrębnić obszar jednostki gospodarczej, w ramach którego następuje dystrybucja towarów lub świadczenie usług $\mathrm{w}$ określonym środowisku ekonomicznym, który podlega ryzyku i charakteryzuje się poziomem zwrotu z poniesionych nakładów inwestycyjnych, różnym od tych, które są właściwe dla innych obszarów, działających w odmiennym środowisku ekonomicznym" (IAS14R.9). Należy również dodać, że w przypadku segmentów geograficznych standard dopuszcza dwie możliwości przy ich definiowaniu. Te obszary mogą zostać określone w oparciu o (IAS14R.13):

- lokalizację aktywów - należy przez to rozumieć, że podczas dokonywania podziału prowadzonej działalności ze względu na jej geograficzne rozczłonkowanie dokonuje się jej ze względu na położenie zakładów produkcyjnych lub punktów świadczenia usług;

- lokalizację rynków i klientów - w tym przypadku należy kierować się geograficznym rozczłonkowaniem odbiorców towarów lub świadczonych usług, czyli rynków, które są przez daną jednostkę obsługiwane.

Punktem wyjścia przy podziale działalności na odrębne segmenty jest istniejąca $w$ ramach jednostki gospodarczej struktura organizacyjna oraz wewnętrzny system sprawozdawczości finansowej. Zdaniem twórców standardu powinno to odzwierciedlać zróżnicowanie realizowanych w poszczególnych obszarach działalności stóp zwrotu oraz towarzyszących im poziomów ryzyka (IAS14R.13). W sytuacji, gdy istniejąca struktura organizacyjna oraz wewnętrzny system sprawozdawczości są zorganizowane w inny sposób aniżeli kryterium produktowe i geograficzne, segmenty działalności należy wyodrębnić zgodnie z wymogami niniejszego standardu przez przejście na niższy poziom segmentacji działalności (IAS14R.30). Należy w ten sposób postępować do momentu, gdy wyodrębnione obszary działalności będą spełniać kryterium segmentów branżowych i geograficznych zawarte w par. 9 standardu (IAS14R.32).

Wyodrębnione w ten sposób segmenty działalności uznaje się za segmenty sprawozdawcze wówczas, gdy większość ich przychodów ze sprzedaży pocho- 
dzi od klientów zewnętrznych oraz spełniają one co najmniej jeden z następujących progów ilościowych (IAS14R.35):

- przychody segmentu ze sprzedaży na rzecz zewnętrznych klientów lub z transakcji realizowanych z innymi segmentami stanowią 10\% lub więcej łącznych zewnętrznych i wewnętrznych przychodów wszystkich segmentów;

- wynik segmentu niezależnie od tego, czy jest nim zysk czy strata, stanowi 10\% lub więcej połączonego wyniku wszystkich segmentów, które odnotowały zysk, lub wszystkich segmentów, które poniosły stratę, w zależności od tego, która z tych wartości wyrażona jako wartość bezwzględna jest większa;

- aktywa segmentu stanowią 10\% lub więcej ogółu aktywów wszystkich segmentów.

Informacje, które należy ujawnić na temat każdego z wyodrębnionych segmentów sprawozdawczych - branżowych i geograficznych - zgodnie z wymogami standardu, zaprezentowano syntetycznie na schemacie 3 .

Schemat 3. Informacje wymagane do ujawnienia przez IAS14R

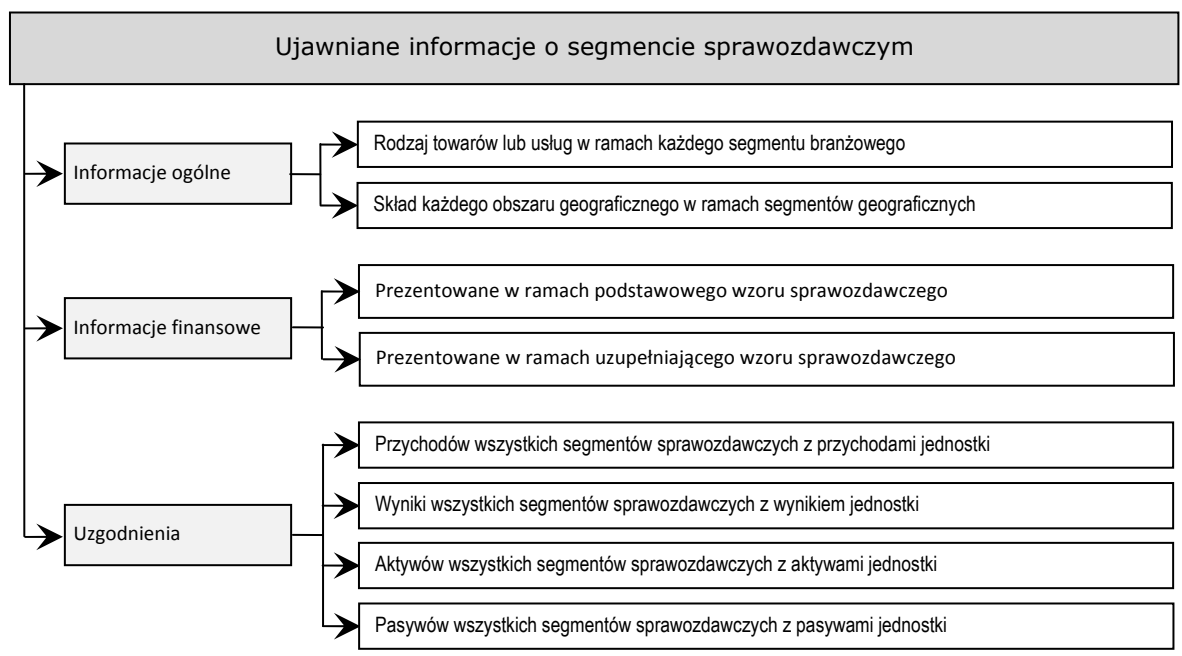

Źr ó d ło : opracowanie własne na podstawie: International Accounting Standard 14 Segment Reporting, International Accounting Standards Committee Foundation, par. 50, 67, 68, 81, http:// www.ifrs.org (dostęp 30.10.2011). 


\section{ZASADNOŚĆ ZMIANY IAS14 NA IAS14R W KONTEKŚCIE BADAŃ EMPIRYCZNYCH}

Ocena zasadności zmiany standardów sprawozdawczości według segmentów wymaga przytoczenia wniosków płynących z badań empirycznych w tym zakresie. Do grona ważniejszych należą badania prowadzone przez Donne L. Street i Nancy B. Nichols (Street, Nichols 2002: 91-113) oraz Jenice Prather-Kinsey i Gary K. Meek (Prather-Kinsey, Meek 2004: 213-234). Wszyscy oni stwierdzili, że wprowadzenie IAS14R przyczyniło się do wzrostu liczby ujawnianych segmentów działalności oraz zwiększenia zakresu ujawnianych informacji o tych obszarach. Street i Nichols dokonały bardziej szczegółowej analizy, z której wynikało, że zwiększyła się liczba ujawnianych segmentów branżowych, ale liczba segmentów geograficznych pozostała bez zmian. Dodatkowo wzrosła średnia liczba ujawnionych segmentów działalności na jednostkę gospodarczą - z 3,94 do 4,04. Poddały one również szczegółowej analizie zakres ujawnianych informacji o segmentach, dokonując jego podziału na obligatoryjny dla IAS14 i IAS14R oraz ten wymagany jedynie przez IAS14R. W pierwszym przypadku nowy standard dostarczył większej liczby wymaganych informacji aniżeli jego poprzednik. W drugim przypadku również wypadł lepiej aniżeli IAS14. Przy czym należy podkreślić, że poprzednik tych informacji nie wymagał.

Powyższe rozważania budzą wątpliwość co do istotności poczynionej zmiany. IAS14R wypada lepiej od IAS14, ale trzeba podkreślić, że nieznacznie lepiej. Mogą o tym świadczyć wyniki badań Street i Nichols, które ujawniły, że w ramach IAS14 prezentacji segmentów dokonało 127 jednostek spośród 210 poddanych badaniu. Po wprowadzeniu IAS14R liczba tych podmiotów wzrosła do 140 , co stanowi wzrost o nieco ponad $10 \%$. Średnia liczba ujawnianych obszarów działalności wzrosła z 3,94 do 4,04, co stanowi wzrost o jedyne 2,5\%. Podobna sytuacja wystąpiła w przypadku zakresu ujawnianych informacji. On również wzrósł, ale jego poziom nadal pozostawał na niezadowalającym poziomie. Zwracali na to uwagę w szczególności Prather-Kinsey i Meek, twierdząc, że w zakresie ujawnionych informacji o segmentach w ramach IAS14R wyszczególniono poważne braki między tym, co jednostki ujawniły, a tym, czego wymagał od nich standard.

Podsumowując powyższe wyniki badań, należy stwierdzić, że wprowadzenie IAS14R przyczyniło się do zwiększenia liczby jednostek prezentujących segmenty działalności, liczby ujawnianych segmentów oraz informacji na ich temat. W związku z tym można sądzić, że IAS14R dostarcza bardziej uży- 
tecznych decyzyjnie informacji. Należy jednak podkreślić, że poprawa jest nieznaczna w stosunku do poprzednika.

\section{PRZYCZYNY ROZPOCZĘCIA PRAC NAD IFRS8}

W połowie pierwszej dekady XXI w. wprowadzono nowy standard poświęcony sprawozdawczości segmentów działalności - IFRS8, który zastąpił IAS14R od okresów sprawozdawczych rozpoczynających się 1 stycznia 2009 r. i później. Podkreślenia wymaga fakt, że główną przyczyną tej zmiany nie były wady obowiązującego standardu, lecz realizowany przez IASB i FASB proces konwergen$\mathrm{cji}^{5}$ standardów sprawozdawczości finansowej. Proces ten rozpoczął się w dniu 18 września 2002 r. od podpisania przez obie rady umowy pod nazwą „Memorandum of Understanding”. Na wniosek instytucji zajmujących się obrotem papierami wartościowymi do celów krótkoterminowych procesu konwergencji zaliczono ujednolicenie sprawozdawczości według segmentów działalności. W związku z tym przystąpiono do identyfikacji wszelkich różnic występujących między IAS14R a jego amerykańskim odpowiednikiem - Standardem Rachunkowości Finansowej nr 131 Ujawnienia dotyczące segmentów przedsiębiorstwa i informacje powiązane (ang. Statement of Financial Accounting Standard No. 131 Disclosures about Segments of an Enterprise and Related Information, SFAS131), oraz do analizy wyników badań akademickich prowadzonych w tym zakresie, w szczególności w Stanach Zjednoczonych (Karwowski, Świderska 2009: 264).

W związku z tym, że podejście zarządcze zawarte w SFAS131 spotkało się z większą aprobatą aniżeli to zawarte w IAS14R, IASB przystąpiła do prac nad nowym standardem sprawozdawczości według segmentów w ramach IFRS. Przy czym miał on być implementacją rozwiązań zawartych w amerykańskim odpowiedniku jako rezultat realizacji procesu konwergencji.

Podkreślenia wymaga fakt, że proces konwergencji stanowił główną przyczynę rozpoczęcia prac nad nowym standardem, ale sam w sobie jej nie spo-

${ }^{5}$ Przez proces konwergencji należy rozumieć proces harmonizacji systemów rachunkowości reprezentowanych przez FASB oraz IASB, którego celem jest stworzenie globalnych, charakteryzujących się wysoką jakością standardów rachunkowości i sprawozdawczości finansowej, które będą zrozumiałe dla użytkowników oraz akceptowane przez regulatorów rynków kapitałowych na całym świecie. Ten proces rozpoczął się w dniu 18 września 2002 r. od podpisania przez obie rady umowy pod nazwą „Memorandum of Understanding”, znanej również jako „The Norwalk Agreement” (Erchinger, Melcher 2007: 125, 127). 
wodował. Powodem tego były wady IAS14R, które sprawiły, że w analizie porównawczej wypadł on gorzej niż jego amerykański odpowiednik. Do tych wad należy zaliczyć w szczególności:

- małą liczbę jednostek ujawniających informacje o segmentach działalności;

- istotne braki w ujawnianych informacjach o segmentach w stosunku do wymogów zawartych w standardzie;

- niewłaściwe podejście do sprawozdawczości według segmentów skutkujące tworzeniem sztucznych obszarów;

- brak przeciwdziałania zjawisku kosztów własnych.

Mała liczba jednostek ujawniających informacje o segmentach działalności stanowi główną wadę IAS14R. Zwrócono na to uwagę w badaniu prowadzonym przez Gertrudę K. Świderską i Mariusza Karwowskiego. Poddali oni analizie skonsolidowane sprawozdania finansowe polskich grup kapitałowych za okresy 2003 i $2004^{6}$. W wyniku tego stwierdzili, że ujawnienia informacji o segmentach w roku 2003 dokonało jedynie 46\% spośród badanych, a w 2004 - 53\%. Głównym argumentem prezentowanym przez jednostki, które nie ujawniły obszarów działalności, było stwierdzenie, że prowadzona przez nich działalność jest jednorodna (Karwowski, Świderska 2006: 50-60).

Za wadę IAS14R uznano również istotne braki w ujawnianych informacjach o segmentach w stosunku do wymogów standardu. We wspomnianym już badaniu prowadzonym przez Świderską i Karwowskiego stwierdzono również, że ujawnienia podstawowego i uzupełniającego wzoru sprawozdawczego dokonało w roku 2003 jedynie 29 podmiotów spośród 134 poddanych badaniu, co stanowi niecałe $22 \%$. W roku 2004 odsetek tych jednostek wzrósł nieznacznie do poziomu prawie 24\% (Karwowski, Świderska 2006: 50-60). Bardziej szczegółowej analizy zakresu ujawnionych informacji o segmentach dokonali Sławomir Sojak i Tomasz Zimnicki. Poddali oni badaniu sprawozdania finansowe dla roku 2006 spółek giełdowych, których centrala znajduje się na terenie województwa kujawsko-pomorskiego. Stwierdzili oni, że w ramach podstawowe-

${ }^{6}$ Należy podkreślić, że standardy IFRS zaczęły obowiązywać jednostki gospodarcze sporządzające skonsolidowane sprawozdania finansowe i prowadzące działalność w Polsce dopiero dla okresów sprawozdawczych rozpoczynających się 1 stycznia 2005 r. i później. Przed tym okresem obowiązek ujawnienia informacji o segmentach działalności według IAS14R nakładał na te podmioty par. 3 ust. 2 Rozporządzenia Rady Ministrów z dnia 19 marca 2002 r. zmieniającego rozporządzenie w sprawie szczegółowych warunków, jakim powinien odpowiadać prospekt emisyjny oraz skrót prospektu (Dz. U. 2002.36.328). 
go wzoru sprawozdawczego ujawnienia informacji o przychodach i wynikach segmentów dokonała tylko połowa spośród badanych podmiotów, ujawnienia aktywów, pasywów, nakładów inwestycyjnych i amortyzacji segmentów niecałe $17 \%$. Przepływów pieniężnych segmentu nie ujawniła żadna z badanych jednostek. W przypadku uzupełniającego wzoru sprawozdawczego wymaganych przez standard informacji o segmentach ujawniła jedynie połowa badanych podmiotów. Stwierdzili oni również, że wykorzystanie ujawnionych informacji o segmentach do oszacowania rentowności sprzedaży, aktywów, kapitałów oraz nakładów inwestycyjnych poszczególnych obszarów danej jednostki możliwe jest tylko w przypadku 8\% badanych podmiotów (Sojak, Zimnicki 2008: 135-163).

Niewłaściwe podejście do sprawozdawczości według segmentów skutkujące tworzeniem sztucznych obszarów uznano za kolejną wadę IAS14R. Jej potwierdzeniem może być wniosek płynący ze studium przypadku Grupy Kapitałowej notowanej na Giełdzie Papierów Wartościowych w Warszawie przeprowadzonego przez Tomasza Zimnickiego. Analiza ujawnionych informacji o segmentach w rocznym i śródrocznych sprawozdaniach finansowych dla roku 2006 oraz wywiad z osobą odpowiedzialną za przygotowanie tych informacji wykazały, że jednostka nie posiada wyodrębnionych obszarów działalności na potrzeby sprawozdawczości wewnętrznej. W związku z tym nie ma odpowiednio dostosowanego systemu ewidencji księgowej, który umożliwiałby przygotowanie wiarygodnych informacji o segmentach działalności na potrzeby sprawozdawczości zewnętrznej. Dodatkowo ujawnione przychody i wyniki segmentów w sprawozdaniu rocznym powstały w wyniku przeprowadzonych szacunków. Brak ujawnienia informacji na temat aktywów, pasywów, nakładów inwestycyjnych, amortyzacji i przepływów pieniężnych w poszczególnych obszarach działalności wynikał z braku racjonalnych podstaw do dokonania szacunków. Należy również dodać, że podmiot nie ujawnił segmentów działalności w sprawozdaniach kwartalnych, gdyż czas na przygotowanie tych raportów był zbyt krótki, by móc dokonać odpowiedniego przekształcenia posiadanych informacji finansowych. W związku z powyższym powstaje wątpliwość co do wiarygodności ujawnionych informacji o segmentach (Zimnicki 2008: 191-212).

Za wadę IAS14R uznano również brak przeciwdziałania zjawisku kosztów własnych. Zwrócili na to uwagę Street i Nichols, które poddały analizie sprawozdania finansowe 160 jednostek gospodarczych dla okresów od 1999 do 2002 r. Wnioski płynące z badania potwierdzają, że wprowadzenie nowego standardu nie przyczyniło się do ograniczenia ukrywania obszarów charakte- 
ryzujących się ponadprzeciętnymi wynikami przez łączenie ich z innymi segmentami. W związku z tym występuje pewne ograniczenie użyteczności decyzyjnej tego typu informacji (Street, Nichols 2007: 51-68).

\section{SPRAWOZDAWCZOŚĆ SEGMENTÓW DZIAŁALNOŚCI WEDEUG IFRS8}

Przytoczone wady IAS14R spowodowały, że w roku 2006 wydano nowy standard - IFRS8, który zastąpił poprzednika od okresów sprawozdawczych rozpoczynających się 1 stycznia 2009 r. i później. W stosunku do IAS14R wprowadził on całkowicie nowe podejście do sprawozdawczości według segmentów działalności. Określa się je mianem podejścia zarządczego. Należy przez nie rozumieć taki podział działalności na odrębne obszary, jaki został wprowadzony przez osoby zarządzające danym podmiotem gospodarczym, niezależnie od tego, czy ten podział został oparty na kryterium produktów lub usług, obszarów geograficznych, klientów, formy prawnej jednostek wchodzących w skład grupy kapitałowej, czy też jeszcze innym. Punktem wyjścia przy określenia segmentów działalności jest zatem istniejący w ramach sprawozdawczości wewnętrznej podział jednostki odpowiadający jej strukturze organizacyjnej i funkcjonującemu tam systemowi zarządzania.

Standard wśród tak określonych segmentów działalności wyróżnia segmenty operacyjne. Rozumie przez nie te części składowe jednostki (IFRS8.5):

- które angażują się w działalność gospodarczą, w rezultacie czego mogą uzyskiwać przychody i ponosić koszty;

- których wyniki są regularnie przeglądane przez główny organ odpowiedzialny za podejmowanie decyzji operacyjnych w jednostce oraz stanowią podstawę alokacji zasobów i oceny wyników prowadzonych tam działalności;

- w przypadku których dostępne są odrębne informacje finansowe.

Segment operacyjny uznaje się za segment sprawozdawczy wtedy, gdy spełnia on kryterium segmentu operacyjnego (IFRS8.5), powstał na skutek połączenia dwóch lub większej liczby segmentów operacyjnych zgodnie z zawartym w standardzie kryterium łączenia segmentów (IFRS8.12) oraz przekroczył progi ilościowe (IFRS8.13). Informacje, które należy ujawnić zgodnie z wymogami standardu w odniesieniu do każdego z segmentów sprawozdawczych, zaprezentowano na schemacie 4 . 
Schemat 4. Informacje wymagane do ujawnienia przez IFRS8

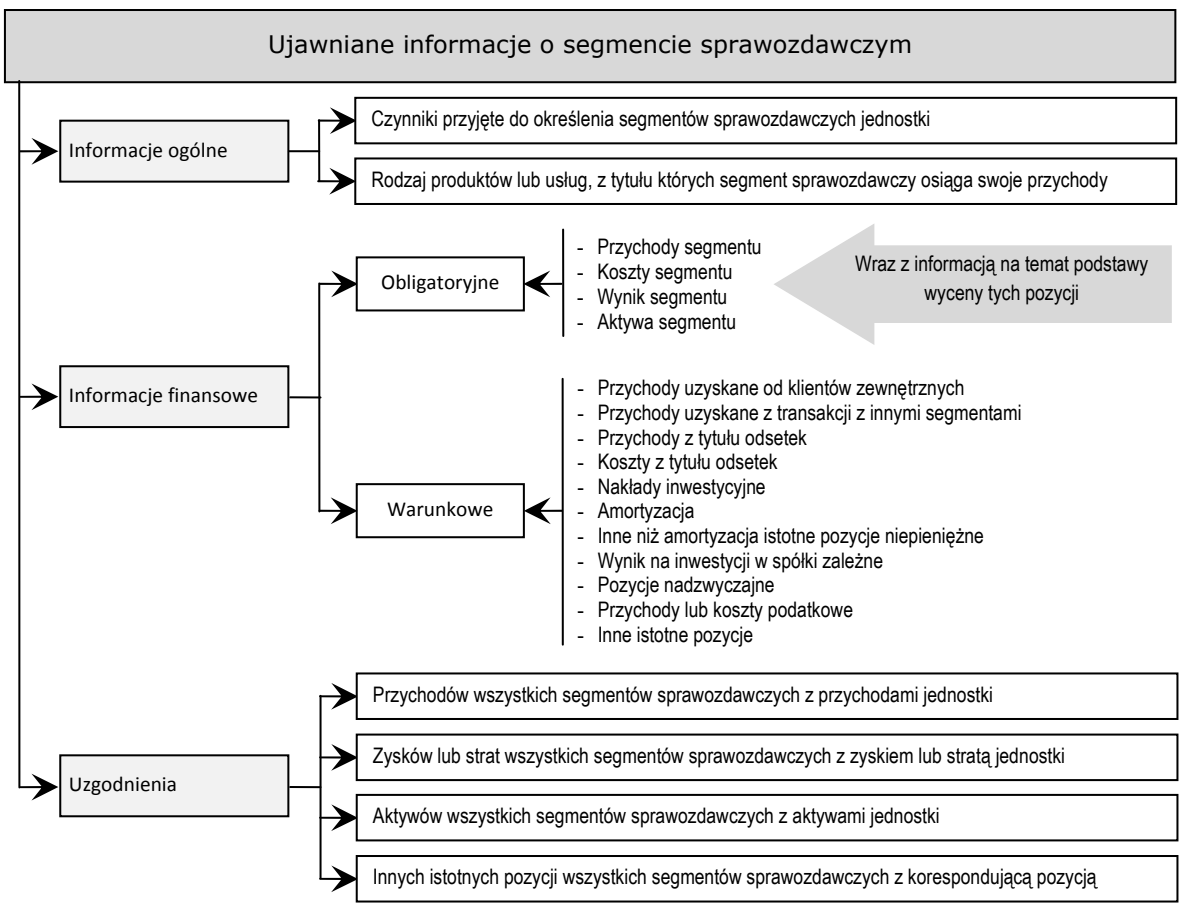

Źr ó d ł o : opracowanie własne na podstawie: International Financial Reporting Standard 8 Operating Segments, International Financial Reporting Standards Foundation, par. 20-24, 28, http:// www.ifrs.org (dostęp 30.10.2011).

\section{ZAKOŃCZENIE}

Podsumowując powyższe rozważania, należy zaznaczyć, że w ramach IFRS stworzono trzy różne standardy sprawozdawczości według segmentów działalności. Pierwszym z nich był IAS14, który funkcjonował przez ponad 16 lat. Pod koniec tego okresu rozpoczęto prace nad IAS14R. Był to w szczególności wynik istotnych wad IAS14, do których zaliczono: zbyt ogólne definicje segmentów przemysłowych i geograficznych, mało precyzyjne wytyczne przy identyfikacji i pomiarze takich składowych segmentu, jak: przychody, koszty, wynik oraz aktywa, a także braki w ujawnieniach informacji o segmentach wymaganych przez standard oraz zbyt małą ilość wymaganych informacji. Należy podkreślić, że nie tylko powyższe wady przyczyniły się do rozpoczęcia prac 
nad nowym standardem. Istotny udział w tym miał również wzrost znaczenia sprawozdawczości według segmentów działalności na świecie oraz naciski na ten obszar ze strony liczących się w skali świata międzynarodowych organizacji, takich jak: UE, OECD, UN oraz IOSCO.

W roku 1998 wprowadzono IAS14R, który nie stanowił całkowicie odmiennego podejścia do sprawozdawczości według segmentów, ale charakteryzował się doprecyzowaniem podejścia prezentowanego w ramach IAS14. Przytoczone wyniki badań w kontekście praktycznego zastosowania obu standardów przez jednostki gospodarcze dowiodły wyższości IAS14R nad IAS14. Wynika to z faktu, że wprowadzenie nowego standardu przyczyniło się do wzrostu liczby podmiotów ujawniających informacje o segmentach, liczby ujawnianych segmentów działalności oraz zwiększenia zakresu ujawnianych informacji o tych obszarach. Przy czym trzeba podkreślić, że poprawa była nieznaczna.

IAS14R funkcjonował przez ponad 10 lat. Po tym okresie wprowadzono nowy standard sprawozdawczości według segmentów - IFRS8. Podkreślenia wymaga fakt, że główną przyczyną rozpoczęcia prac nad zmianą standardu był realizowany przez IASB i FASB proces konwergencji standardów sprawozdawczości finansowej. Przy czym na uwagę zasługuje również to, że sam proces zmiany nie spowodował. Przyczyniły się do tego zidentyfikowane wady IAS14R, w wyniku których w analizie porównawczej wypadł on gorzej niż jego amerykański odpowiednik - SFAS131. Do tych wad należy zaliczyć w szczególności: małą liczbę jednostek ujawniających informacje o segmentach działalności, istotne braki w ujawnianych informacjach o segmentach w stosunku do wymogów zawartych w standardzie, niewłaściwe podejście do sprawozdawczości według segmentów skutkujące tworzeniem sztucznych obszarów oraz brak przeciwdziałania zjawisku kosztów własnych.

IFRS8 został wprowadzony w roku 2009. Stanowił on całkowicie nowe podejście do sprawozdawczości według segmentów działalności, opierając się na tym, jak jednostka jest zorganizowana i zarządzana. Brakuje badań w zakresie praktycznego zastosowania IFRS8 przez jednostki gospodarcze i płynących z tego wniosków. Należy także zauważyć, że standard ten stanowi kopię amerykańskiego SFAS131, który został wypracowany w ramach systemu anglosaskiego, a wprowadza się go do systemu kontynentalnego. W związku z tym nie można jednoznacznie stwierdzić, czy wprowadzona zmiana standardów - IAS14R na IFRS8 - była zasadna. Potrzebne są odpowiednie badania empiryczne. 


\begin{tabular}{|c|c|c|c|c|c|}
\hline \multirow{5}{*}{ 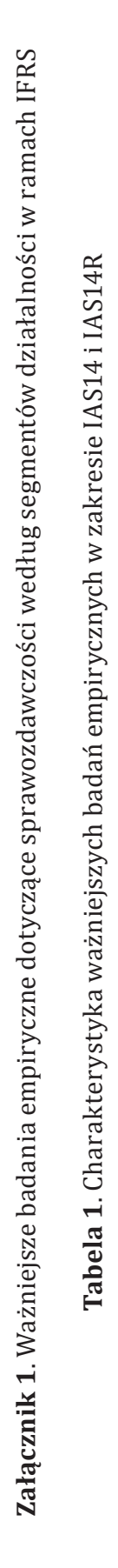 } & $\begin{array}{l}0 \\
\frac{i}{0} \\
\frac{0}{N}\end{array}$ & 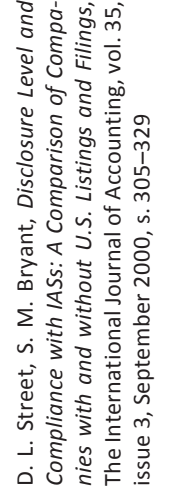 & 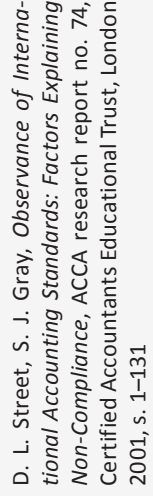 & 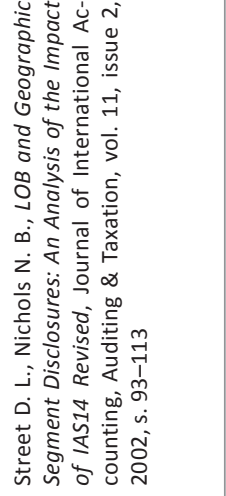 & 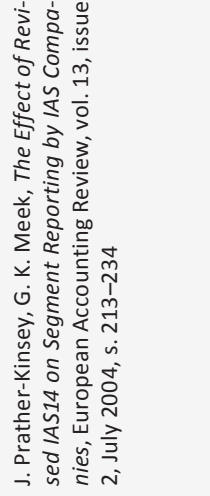 \\
\hline & 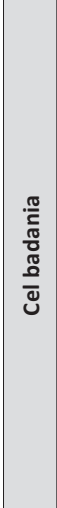 & 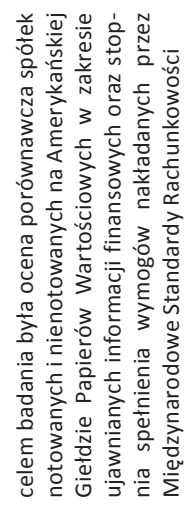 & 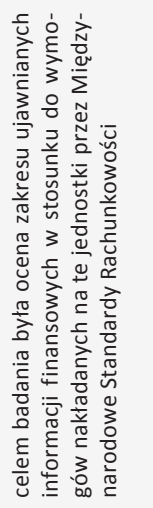 & 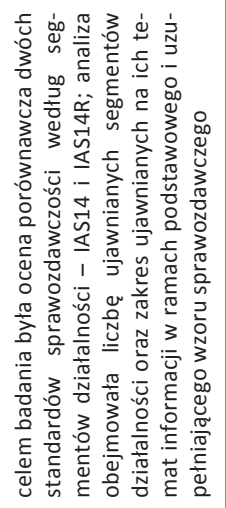 & 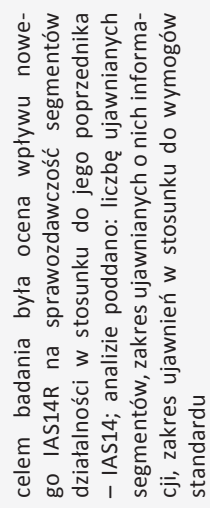 \\
\hline & 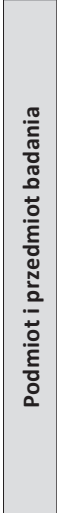 & 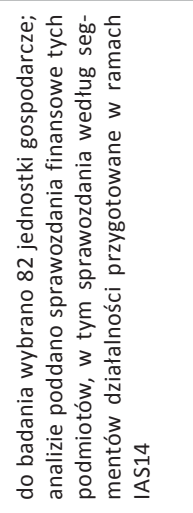 & 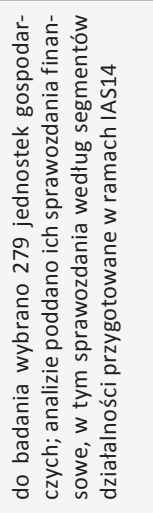 & 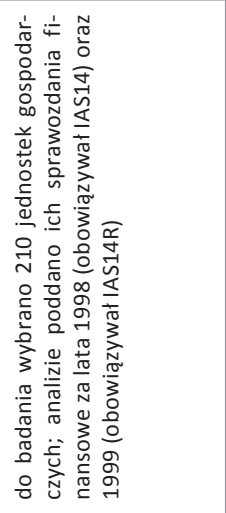 & 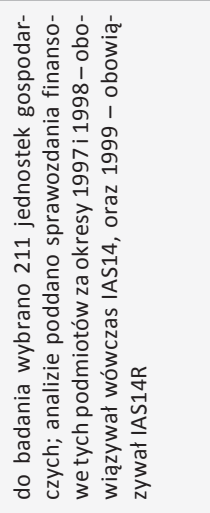 \\
\hline & $\mid$\begin{tabular}{l} 
N \\
0 \\
0 \\
\multirow{3}{*}{}
\end{tabular} & 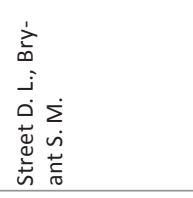 & 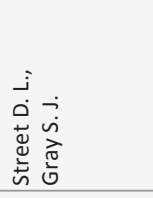 & 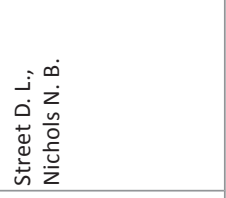 & 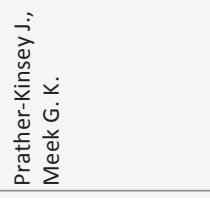 \\
\hline & $\stackrel{2}{3}$ & $r$ & $N$ & $m$ & 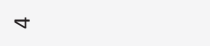 \\
\hline
\end{tabular}




\begin{tabular}{|c|c|c|c|c|}
\hline & 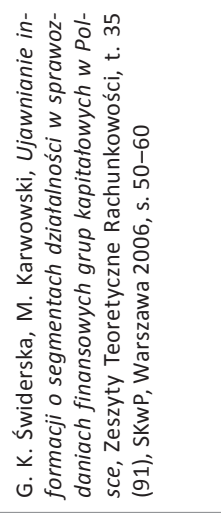 & 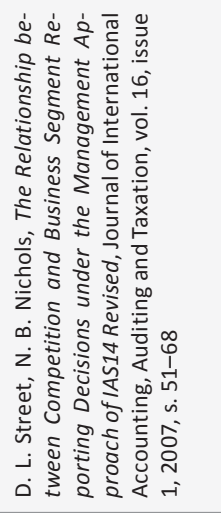 & 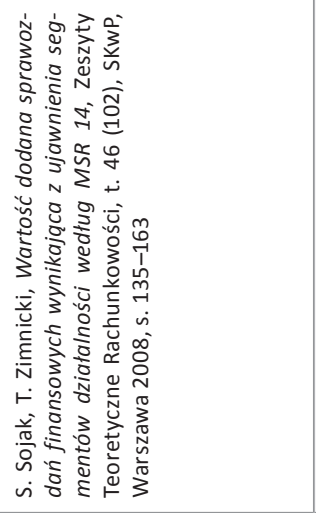 & 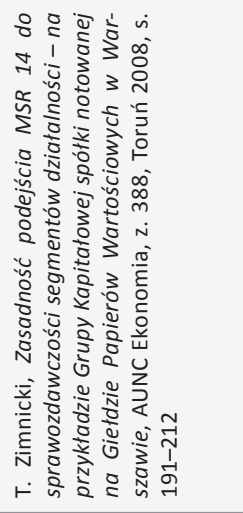 \\
\hline & 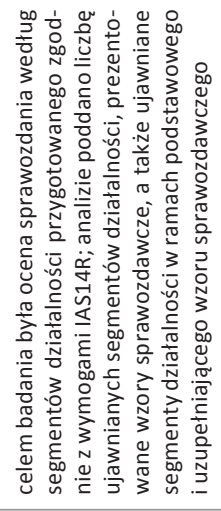 & 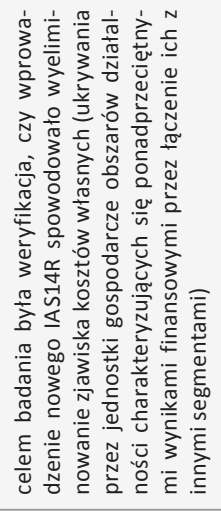 & 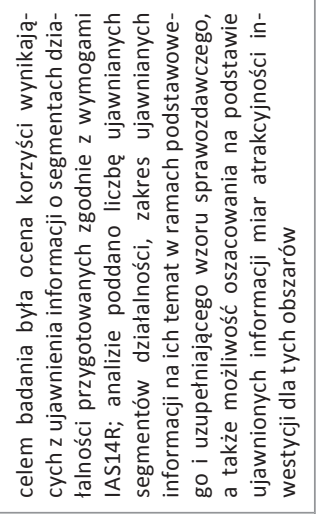 & 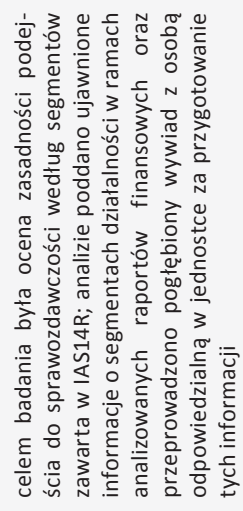 \\
\hline 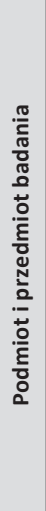 & 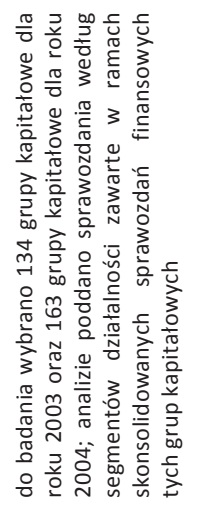 & 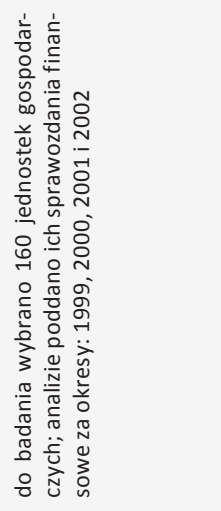 & 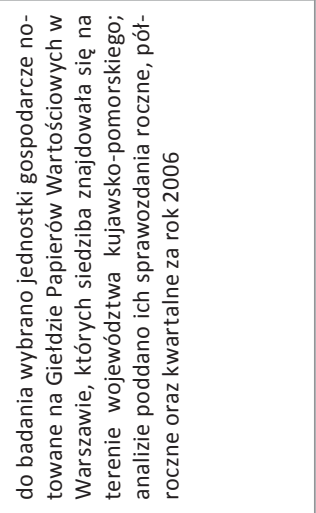 & 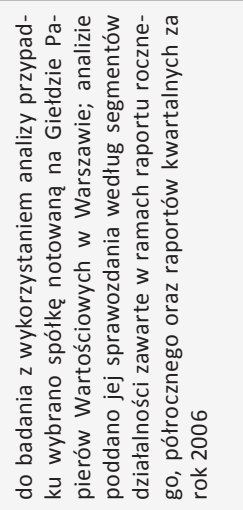 \\
\hline 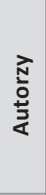 & 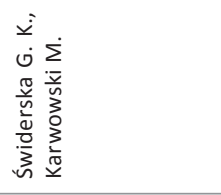 & 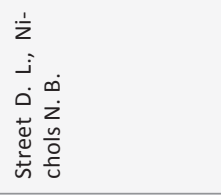 & 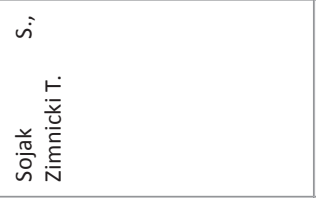 & 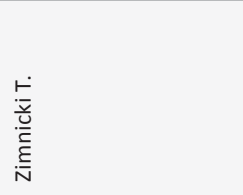 \\
\hline$\stackrel{\dot{S}}{ }$ & in & 6 & $\wedge$ & $\infty$ \\
\hline
\end{tabular}




\section{IITERATURA}

Albrecht W. D., Chipalkatti N. (1998), New Segment Reporting, CPA Journal, vol. 68, issue 5.

Erchinger H., Melcher W. (2007), Convergence between US GAAP and IFRS: Acceptance of IFRS by the US Securities and Exchange Commission (SEC), Accounting in Europe, vol. 4.

International Accounting Standard 14 Reporting Financial Information by Segment, International Accounting Standards Committee Foundation, http://www.ifrs.org (dostęp 4.11.2011).

International Accounting Standard 14 Segment Reporting, International Accounting Standards Committee Foundation, http://www.ifrs.org (dostęp 30.10.2011).

International Financial Reporting Standard 8 Operating Segments, International Financial Reporting Standards Foundation, http://www.ifrs.org (dostęp 30.10.2011).

Karwowski M., Świderska G. K. (2006), Ujawnianie informacji o segmentach działalności w sprawozdaniach finansowych grup kapitałowych $w$ Polsce, Zeszyty Teoretyczne Rachunkowości, t. 35 (91), SKwP, Warszawa.

Karwowski M., Świderska G. K. (2009), Segmenty zarządcze w rachunkowości finansowej i zarządczej, [w:] Problemy współczesnej rachunkowości, Pracownicy Katedry Rachunkowości SGH (red.), Szkoła Główna Handlowa, Warszawa.

McConnell P., Pacter P. (1995), IASC and FASB Proposals Would Enhance Segment Reporting, CPA Journal, vol. 65, issue 8.

MSR 14 Sprawozdawczość dotycząca segmentów działalności (2004), Międzynarodowe Standardy Sprawozdawczości Finansowej (MSSF), t. 1, SKwP, Warszawa.

MSSF 8 Segmenty operacyjne (2007), Międzynarodowe Standardy Sprawozdawczości Finansowej (MSSF), t. 1, SKwP, Warszawa.

Pacter P. (1993), Reporting Disaggregated Information, Financial Accounting Standards, Norwalk.

Prather-Kinsey J., Meek G. K. (2004), The Effect of Revised IAS14 on Segment Reporting by IAS Companies, European Accounting Review, vol. 13, issue 2.

Rozporządzenia Rady Ministrów z dnia 19 marca 2002 r. zmieniające rozporządzenie w sprawie szczegółowych warunków, jakim powinien odpowiadać prospekt emisyjny oraz skrót prospektu (Dz. U. 2002.36.328).

Sojak S., Zimnicki T. (2008), Wartość dodana sprawozdań finansowych wynikająca z ujawnienia segmentów działalności według MSR 14, Zeszyty Teoretyczne Rachunkowości, t. 46 (102), SKwP, Warszawa.

Street D. L., Bryant S. M. (2000), Disclosure Level and Compliance with IASs: A Comparison of Companies with and without U.S. Listings and Filings, The International Journal of Accounting, vol. 35, issue 3.

Street D. L., Gray S. J. (2001), Observance of International Accounting Standards: Factors Explaining Non-Compliance, ACCA research report no. 74, Certified Accountants Educational Trust, London. 
Street D. L., Nichols N. B. (2002), LOB and Geographic Segment Disclosures: An Analysis of the Impact of IAS14 Revised, Journal of International Accounting, Auditing \& Taxation, vol. 11, issue 2 .

Street D. L., Nichols N. B. (2007), The Relationship between Competition and Business Segment Reporting Decisions under the Management Approach of IAS14 Revised, Journal of International Accounting, Auditing and Taxation, vol. 16, issue 1.

Zimnicki T. (2008), Zasadność podejścia MSR 14 do sprawozdawczości segmentów działalności - na przykładzie Grupy Kapitałowej spółki notowanej na Giełdzie Papierów Wartościowych w Warszawie, AUNC Ekonomia, z. 388, Toruń. 
